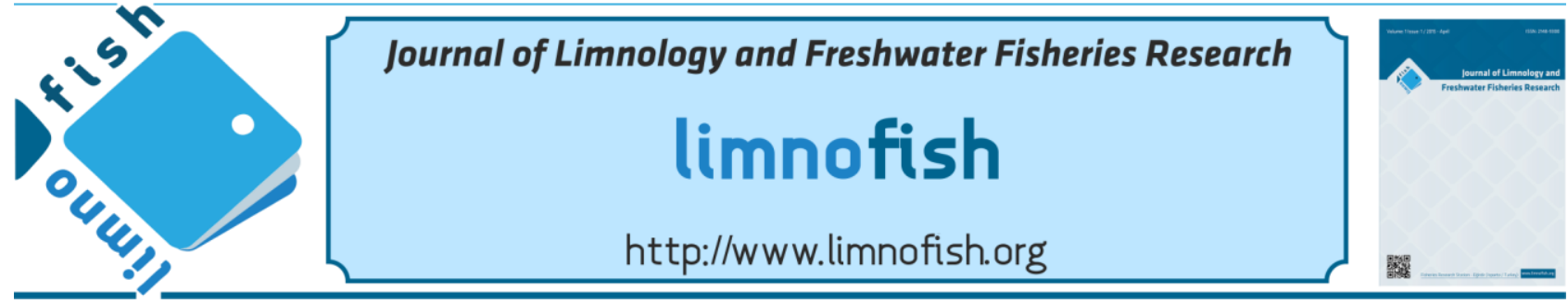

\title{
Effect of $\mathrm{CuSO}_{4}$ on Toxicity of Nano Zinc Oxide (nZnO) in Carp Fish (Cyprinus carpio L.)
}

\author{
Shahbaa Khalil Ebraheem AL-TAEE, Alaa Hussain Ali AL-HAMDANI* \\ University of Mosul, Department of Pathology and Poultry Diseases, College of Veterinary, Mosul, Iraq
}

\section{A B STRACT}

Copper sulfate $\left(\mathrm{CuSO}_{4}\right)$ was used to reduce the toxic effect of nano zinc oxide ( $\mathrm{nZnO})$ in carp (Cyprinus carpio L.). Copper sulfate $(0.3 \mathrm{mg} / \mathrm{L})$ was used for 1 hour in carp fish exposed to $\mathrm{n} \mathrm{ZnO}$ in sub-lethal concentration $(9 \mathrm{mg} / \mathrm{L})$ for seven days. Also for comparison second group were only exposed to $\mathrm{n} \mathrm{ZnO}$ in sub-lethal concentration $(9 \mathrm{mg} / \mathrm{L})$ for seven days. There were significant changes in concentration of Metallothionein $(M T)$ and some biochemical parameters in serum of fish blood in all groups compared with non-treated groups. $\mathrm{CuSO}_{4}$ has play a major role in reducing the toxicity of $\mathrm{n} \mathrm{ZnO}$ in some blood serum parameters.

Keywords: Copper sulfate, nano zinc oxide toxicity, carp fish

\section{ARTICLE INFO}

\section{RESEARCH ARTICLE}

Received : 27.04.2015

Revised : : 17.11.2015

Accepted : :19.11.2015

Published : 20.12.2015

DOI: $10.17216 /$ LimnoFish-5000114439

* CORRESPONDING AUTHOR

al2006hamdani@yahoo.com

Tel : +0 7701630998

\section{How to Cite}

Al-Taee SKE, Al-Hamdani AHA. 2015. Effect of $\mathrm{CuSO}_{4}$ on Toxicity of Nano Zinc Oxide (nZnO) in Carp Fish (Cyprinus carpio L.). LimnoFish. 1(3):99-102. doi: 10.17216/LimnoFish-5000114439

\section{Introduction}

Nano zinc oxide is used in many industries including cosmetics, ointments for protective of the sun, the manufacture of dyes, glass, cement industry and optical filters industry (Rekha et al. 2010). Therefore it enters directly or indirectly to theaquatic environment, and have toxic effect on the biology of aquatic organisms and then to humans (Yu et al. 2011).

Nano zinc oxide enters fish body through gills, digestive tract and skin. Because of the small practical size, it has the ability to penetrate the cell membrane, leading to an imbalance in permeability of cell membrane and has a role in the liberation of free oxygen radical and the occurrence of oxidative stress (Ma et al. 2013). The ability to cause oxidative stress $(O S)$ is one of the most important mechanisms of toxicity of nanomaterials within the cell due to the overlap between the electron donor or vital receptor sites and acceptor active site with a molecule of oxygen and this leads to the formation of Superoxide radical $(O-2)$. Thus they stimulate formation of reactive oxygen species $(R O S)$ and the depletion of antioxidants including glutathione and consequently oxidative stress ( $\mathrm{Nel}$ et al. 2006).

Copper compounds are important in prevention and treatment in fish diseases, as they are used in the control of diseases that infect fish at concentration 0.3-2 $\mathrm{mg} / \mathrm{L}$ (Braunbeck1990). Also they are used in the eradication of parasitic infections and protozoa (Carneiro et al. 2005), bacterial disease that infect fish as an anti-fungal fungicide and herbicide (Reddy et al. 2006).

This research was done to determine the effect of copper sulfate on the nano $\mathrm{ZnO}$ toxicity.

\section{Materials and Methods}

Fish

Sixty fish of Cyprinus carpio $(150 \pm 10$ g) were obtained from livestock/Faculty of Agriculture/University of Mosul, and kept in glass aquarium $(40 \times 40 \times 80 \mathrm{~cm})$ at dechlorinated water of $7.5 \mathrm{pH}$ and $23 \pm 2{ }^{\circ} \mathrm{C}$ with continuous oxygenation and feeding for 7 days. 
Feeding was stopped $24 \mathrm{~h}$ before starting of the experiment.

\section{Materials}

1-Nano zinc oxide (N ZnO) from Shijiazhuang sunpower Co. China.

2- Copper sulfate $\left(\mathrm{CuSO}_{4}\right)$ from the local market.

3-Metallothionein (MT-2 ELIZA Kit) Cusabi Co. China.

4-Alanine amino Transferase (ALT-Kit) Biolabo Co. France.

5-Alkaline-Phosphatase (ALP-Kit) Biolabo Co. France.

6-Creatinine Kit (CK-Kit) Biolabo Co. France.

\section{Experimental Design}

The fish were divided randomly into 4 groups of 15 in each:

Group 1: Kept in dechlorinated water only.

Group 2: Treated with $\mathrm{n} \mathrm{ZnO}$ in sub-lethal concentration $(9 \mathrm{mg} / \mathrm{L})$ for seven days only continuously.

Group 3: Treated with $\mathrm{n} \mathrm{ZnO}$ in sub-lethal concentration $(9 \mathrm{mg} / \mathrm{L})$ then treated with $\mathrm{CuSO}_{4}(0.3 \mathrm{mg} / \mathrm{L}$ according to Braunbeck1990) for one hour only then $\mathrm{nZnO}$ for seven days continuously.

Group 4: Treated with $0.3 \mathrm{mg} / \mathrm{L} \mathrm{CuSo} 4$ and then kept in dechlorinated water only for seven days.

Fish blood was collected after 24 hours and 7days of the treatment from the all groups for determination of the following serum parameters (15 fish in each collected period, and the study mention all fish group so it mean 15 fish):

1- Metallothionein (MT) concentration.

This was done by mean of Enzyme immunosurbent Assay (ELISA).

2-The activity of Alanine amino Transferase ALT.

This was done by determined the sample colorimetric or determined the Alanine amino Transferase enzyme activity (IU/l) in serum by mean of Spectrophotometer at 505 nanometer.

3-The activity of Alkaline Phosphatase ALP.

This was done by determined the sample colorimetric for determined the Alkaline Phosphatase enzyme activity (IU/l) in serum by mean of Spectrophotometer at 505 nanometer.

4-Creatinine Kinase $C K$ in serum.

It is a method to determine the interaction chromatography colorimetric reaction of Creatinine with alkaline pirate of the unknown sample in the spectrophotometer device and at a wavelength of 490 nanometers, and calculates the concentration of the enzyme $\mathrm{mg} / \mathrm{dl}$.

\section{Statistical Analysis}

Statistical analysis have been done according to SAS 9, 2001.

\section{Results}

Results showed that there was a significant increase $(p<0.01)$ in level of metallothionein concentration after $24 \mathrm{~h}$ of treatment in Group 2 and Group 3 compared with the other groups (Table 1). But there wasn't significant difference between the Group 1 and Group 4 after $24 \mathrm{~h}$ and after 7 days of treatment.

The activity of $A L T$ showed significant increase $(p<0.01)$ after $24 \mathrm{~h}$ and 7 days of treatment in Group 2 and 4 but there wasn't significant difference between the Group 1 and Group 4 (Table 2).

There are no change in the activity of $A L P$ after treatment with the $\mathrm{n} \mathrm{ZnO}$ and treatment with $\mathrm{CuSO}_{4}$ after $24 \mathrm{~h}$ but after 7 days of treatment with $\mathrm{CuSO}_{4}$. There was significant increase $(p<0.01)$ compared with the other groups (Table 3 ).

This study showed that there was no significant difference $(p<0.01)$ of creatinine levels between all four groups and the same group in different periods (Table 4).

Table 1. Effect of nano zinc oxide with copper sulfate on the $M T$ concentration in the serum of the fish at different period of treatment.

\begin{tabular}{lcc}
\hline & \multicolumn{2}{c}{$\begin{array}{c}\text { MT concentration } \\
\text { Nano g/ml (Mean } \pm \text { SD) }\end{array}$} \\
\cline { 2 - 3 } & after 24 hr & after 7 days \\
\hline Group 1 (water only) & $10.60 \pm 0.05^{\mathrm{a}}$ & $10.60 \pm 0.05^{\mathrm{a}}$ \\
Group 2 (N ZnO) & $15.15 \pm 2.61^{\mathrm{c}}$ & $5.10 \pm 1.49^{\mathrm{d}}$ \\
Group 3 (N ZnO with $\left.\mathrm{CuSO}_{4}\right)$ & $6.06 \pm 0.61^{\mathrm{b}}$ & $3.65 \pm 1.71^{\mathrm{d}}$ \\
Group 4 $\left(\mathrm{CuSO}_{4}\right)$ & $8.12 \pm 0.06^{\mathrm{a}}$ & $9.31 \pm 0.39^{\mathrm{b}}$ \\
\hline
\end{tabular}


Table 2. Effect of nano zinc oxide with copper sulfate on the activity of $A L T$ enzyme in the serum of the fish at different period of treatment.

\begin{tabular}{lcc}
\hline & \multicolumn{2}{c}{$\begin{array}{c}\text { ALT activity in the serum (IU/L) } \\
\text { (Mean } \pm \text { SD) }\end{array}$} \\
\cline { 2 - 3 } Groups & after 24 hr & $98.33 \pm 16.4^{\mathrm{cd}}$ \\
Group 1 (water only) & $98.33 \pm 16.4^{\mathrm{cd}}$ & $168.25 \pm 15.5^{\mathrm{ab}}$ \\
Group 2 (N ZnO) & $146.75 \pm 9.5^{\mathrm{ab}}$ & $80.66 \pm 4.80^{\mathrm{d}}$ \\
Group 3 (N ZnO with $\left.\mathrm{CuSO}_{4}\right)$ & $77.67 \pm 0.33^{\mathrm{d}}$ & $100.67 \pm 2.33^{\mathrm{cd}}$ \\
\hline
\end{tabular}

The different in the letter intend significant difference $p<0.01$

Table 3. Effect of nano zinc oxide with copper sulfate on the activity of $A L P$ enzyme in the serum of the fish at different period of treatment.

\begin{tabular}{llc}
\hline \multirow{2}{*}{ Groups } & \multicolumn{2}{c}{$\begin{array}{c}\text { ALP activity in the serum (IU/L) } \\
\text { (Mean } \pm \text { SD) }\end{array}$} \\
\cline { 2 - 3 } & after 24 hr & $1.90 \pm 0.85^{\mathrm{a}}$ \\
\hline Group 1 (water only) & $1.90 \pm 0.85^{\mathrm{a}}$ & $1.03 \pm 0.46^{\mathrm{ab}}$ \\
Group 2 (N ZnO) & $2.25 \pm 0.02^{\mathrm{ab}}$ & $8.78 \pm 4.16^{\mathrm{cb}}$ \\
Group 3 (N ZnO with $\left.\mathrm{CuSO}_{4}\right)$ & $6.73 \pm 1.56^{\mathrm{ab}}$ & $6.18 \pm 3.47^{\mathrm{a}}$ \\
\hline
\end{tabular}

The different in the letter intend significant difference $p<0.01$

Table 4. Effect of nano zinc oxide with copper sulfate on the activity of $C K$ enzyme in the serum of the fish at different period of treatment.

\begin{tabular}{|c|c|c|}
\hline \multirow{2}{*}{ Groups } & \multicolumn{2}{|c|}{$\begin{array}{l}C K \text { activity in the serum }(\mathrm{mg} / \mathrm{dl}) \\
(\text { Mean } \pm \mathrm{SD})\end{array}$} \\
\hline & after $24 \mathrm{hr}$ & after 7 days \\
\hline Group 1 (water only) & $0.42 \pm 0.11^{\mathrm{abc}}$ & $0.42 \pm 0.11^{\mathrm{abc}}$ \\
\hline Group 2 ( $\mathrm{N} \mathrm{ZnO})$ & $0.22 \pm 0.03^{\mathrm{bc}}$ & $0.11 \pm 0.03^{c}$ \\
\hline Group $3\left(\mathrm{~N} \mathrm{ZnO}\right.$ with $\left.\mathrm{CuSO}_{4}\right)$ & $0.36 \pm 0.05^{\mathrm{bc}}$ & $0.51 \pm 0.03^{\mathrm{ab}}$ \\
\hline Group $4\left(\mathrm{CuSO}_{4}\right)$ & $0.14 \pm 0.01^{\mathrm{c}}$ & $0.42 \pm 0.11^{\mathrm{abc}}$ \\
\hline
\end{tabular}

The different in the letter intend significant difference $p<0.01$

\section{Discussion}

Metallothionein is considered one of the important indicator for aquatic environment pollution and has a role in ionic balance maintenance (Dang et al. 2001; Amaral et al. 2002). Manera and Britti (2006), indicated that zinc considered one of the stimulating of metallothionein to increase in the tissue of the aquatic animals which live in freshwater. The result of this study showed that the concentration of metallothionein increase after $24 \mathrm{~h}$ and seven days of treatment with $\mathrm{nZnO}$ and this result agreed with $(\mathrm{Wu}$ et al.2000). The treatment of the fish with $\mathrm{CuSO}_{4}$ did not cause any increase in metallothionein concentration and this result compatible with the result of DeBoeck et al. (2004). They showed that the treatment of (Oncorhynchus mykiss), fish with 1 micromole of copper ion did not cause an increase of metallothionein concentration in liver tissue.

The amino transfer enzymes like $A L T, A L P$ and creatinine are biochemical indicators in diagnosis of fish diseases and the increase in their activity is indicator of tissue damage due to toxic material (Firat et al. 2011). The result of this study showed no difference of these biomarkers after $24 \mathrm{~h}$ in the all treatment with $\mathrm{nZnO}, \mathrm{CuSO}_{4}$ separately and both of them together compared with the control. But there was an increase in these biomarkers after 7 days of treatment which was due to the damage of the tissue 
with prolonged of the treatment period and this was similar with the research of Mazon 2002. Copper sulfate has a role in decrease the toxic effect of $\mathrm{nZnO}$ and this could be due to the interaction of $\mathrm{CuSO}_{4}$ with the $\mathrm{nZnO}$ to form complex compound of Zinc sulfate. In addition to the bio-effect of the copper in the metabolism and its specific incorporation property with the enzymes like glucose oxidase, xanthine oxidase etc. which play an important role in the cellular respiration, and also an important role of copper sulfate in elimination of free radicals, lipid oxidation and increase of glutathione transferase enzyme. This helps in combine of polluted and toxic material with the glutathione and decrease the toxic effect of them. In addition it has ability to stimulate the antioxidants even in very low concentration (Netpae et al. 2012).

\section{References}

Amaral AF, Alvarado Marigomez L, Cunha R, Hylland K, Soto M. 2002.Autometallography and metallothionein immunohistochemistry in hepatocytes of turbot (Scophthalmus maximus L.) after exposure to cadmium and depuration treatment. Biomarkers. 7(6):491-500.

Braunbeck T, Storch V, Brech H. 1990. Species-specific reaction of liver ultra structure in zebra fish (Branchydanio rerio) and trout (Salmo gairdneri) after prolonged exposure to 4-Chloroaaniline. Arch Environ Contam. Toxicol. 19(3):405-418. cited by: Palacios PS, Risbourg BS, Vernet G. 2000. Biochemical and (Ultra) structural hepatic perturbations of Brachydanio rerio (Teleostei, Cyprinidae) exposed to two sub lethal concentration of copper sulfate. Aquatic Toxicology. 50 (1-2):109-124.

Carneiro PCF, Schorer M, Mikos JD. 2005. Conventional therapeutic treatments on the control of the parasite Ichthyophtirius multifiliis in Rhamdia quelen. Pesquisa Agropecuária Brasileira. 40(2):99-102.

Dang ZC, Berntssen MHG, Lundebye AK, Flik G, Wendelaar Bonga SE, Lock RAC. 2001. Metallothioneinand cortisol receptor expression in gills of Atlantic salmon (Salmo salar), exposed to dietary cadmium. Aquat Toxicol. 53(2):91-101.

DeBoeck G, Meeus W, De Coen W, Blust R. 2004. Tissuespecific $\mathrm{Cu}$ bioaccumulation patterns and differences in sensitivity to water borne $\mathrm{Cu}$ in three fresh water: rainbow trout (Oncorhynchus mykiss), common carp (Cyprinus carpio). Aquat Toxicol. 70(3):179-18.
Firat O, Cogun HY, Yüreroglu TA, Gök G, Firat O, Kargin F, Kötemen Y. 2011.A Comparative study on the effect of a pesticide (Cypermethrine) and two metals (Copper, LEAD) to serum biochemistry of Nile tilapia Oreochromis niloticus. Fish Physiol Bioch. 37(3):657-666. doi: $10.1007 /$ s 10695-011-9466-3

Ma H, Williams PL, Diamond SA. 2013. Ecotoxicity of manufactured $\mathrm{ZnO}$ nanoparticle - A review. Environmental Pollution. 172:76-85. doi: 10.1016/j.envpol.2012.08.011

Manera M, Britti D. 2006. Assessment of blood chemistry normal range in rainbow trout. $\mathrm{J}$ Fish Biol. 69(5):1427-1434.

doi: 10.1111/j.1095-8649.2006.01205.x

Mazon AF, Monterio EAS, Pinheiro GHD, Fernandes MN. 2002. Hematological and physiological changes induced by short term exposure to copper in the fresh water, Prochilodus scrofa. Brazilian J Biol. 62(4A):621-631.

doi: 10.1590/S1519-69842002000400010

Nel A, Xia T, Madler L, Li N. 2006.Toxic potential of material at the nano level. Science. 311(5761):622-627.

doi: $10.1126 /$ science. 1114397

Netpae T, Phalaraksh C, Wongkham W. 2012.Anti oxidant enzyme activities and DNA as biomarker of copper effect on Corbicula fluminea. eJBIO.8(2):19-23.

Reddy R, Pillai R, Adhikari A. 2006.Bioaccumulation of copper in post-Larvae and juveniles of fresh water prawn Macrobrachium rosenbergii (de Man) exposed to sub-lethal levels of copper sulfate. Aquaculture. 252(2-4):356-360.

doi: 10.1016/j.aquaculture.2005.07.010

Rekha K, Nirmala M, Nair MG, Manjula G, Anukaliani A. 2010. Structural, optical, photocatalytic and antibacterial activity of zinc oxide and manganese doped zinc oxide nanoparticle. Physica B: Condensed Matter. 405(15):3180-3185. doi: 10.1016/j.physb.2010.04.042

Wu SM, Weng CF, Hwang JC, Huang C, Hwang PP. 2000. Metallothionein induction in early larval stages of tilapia (Oreochromis massambicus). Physiol Biochem Zool. 73(5):531-537.

Yu LP, Fang T, Xiong DW, Zhu WT, Sima XF. 2011. Comparative toxicity of Nano-ZnO AND Bulk suspensions to zebra fish and the effects of sedimentation, $\mathrm{OH}$ Production and particle dissolution in distilled water. $\mathbf{J}$ Environ Monit. 13(7):1975-1982. doi: $10.1039 / \mathrm{c} 1 \mathrm{em} 10197 \mathrm{~h}$ 